Journal of

Information Systems Engineering

and Business Intelligence

Vol. 4, No. 1, April 2018

Available online at: http://e-journal.unair.ac.id/index.php/JISEBI

\title{
Information Technology Adoption, Corporate Governance, and Bank Performance
}

\author{
Umi Muawanah ${ }^{1)}$, Gunadi $^{2)^{*}}$ \\ ${ }^{1)}$ Department of Accounting, Faculty of Economics and Busineess, Gajayana University \\ Jl. Mertojoyo, Blok L, Merjosari, Kota Malang, Indonesia \\ ${ }^{1)}$ umimuawanah@unigamalang.ac.id \\ ${ }^{2)}$ Departement of Information Systems, Faculty of Engineering and Informatics, Gajayana University \\ Jl. Mertojoyo, Blok L, Merjosari, Kota Malang, Indonesia \\ ${ }^{2)}$ gunadi@unigamalang.ac.id
}

Article history:

Received 28 September 2017

Revised 4 January 2018

Accepted 11 January 2018

Available online 28 April 2018

Keywords:

Bank performance

Corporate governance

Company expenses on IT

Level of IT governance

IT adoption

\begin{abstract}
Many academicians and practitioners have been acknowledging that information technology (IT) adoption could improve company performance. However, previous research indicates contradictory evidence. These inconsistencies can be attributed to variations among the studies in choosing proxy for IT adoption and due to contingent on other factors. This research aims at analyzing the influence of a contingent factor that is corporate governance (CG) concerning the effectiveness of IT adoption in influencing company performance measured by change in return on assets. Two proxies are used for IT adoption: company expenses on IT and the level of the organization managing IT. Data is collected and analyzed from annual reports of all banks listed in Indonesia Stock Exchange from 2011 to 2013. Multiple linear regression models are employed. This research shows that corporate governance practice could improve the effectiveness of IT adoption in improving company performance. This research implies that better CG practices in providing direction and monitoring on IT can lead to better company performance.
\end{abstract}

\section{INTRODUCTION}

Information technology (IT) has been a crucial factor for company's strategic management to gain a competitive advantage [1]. Companies have been racing in investing much of their resources in IT adoption by believing that IT investment can improve company performance or productivity [2][3]Particularly in the banking sector, IT adoption is a critical factor for banks performance [4] especially in supporting the bank's role as an intermediary of financial services.

The critical roles of IT in supporting organization to achieve a high level of performance have been attracting much of research attention [5][6][7]. Specifically, Turel and Bart [8] studied the role of oversight in IT matter by the management team in ensuring organization performance improvement. Sharma et al. [6] Investigated the influence of IT on hospital performance. Tripathy [7] Examined the role of IT in achieving better supply chain management performance of small and medium enterprises. Arora and Arora [9] Showed that IT investment by Indian banks resulted in a positive performance.

Besides these promising influences of IT adoption on the organization, further research indicated that discrepancies of the impact, especially on financial performance, exist [3]. Even, a broader investigation which studied the relationships between IT and organizational performance revealed contradictory evidence [10]. They showed that variables, measurements, and data involved in a study might affect the final results.

\footnotetext{
${ }^{*}$ Corresponding author
} 
In addition to these facts, other research indicated that the productivity paradox over IT investment still exists considering macroeconomic, labor and multi-factor productivity variables [11]. The paradox states that in spite an increase in the IT investment the promised productivity caused by the IT does not seem to realize. However, Masli et al. [12] argued that the existence of productivity paradox is due to inappropriate measures implemented by the studies, time-delay required to realize the value of IT investment, and lack of good design that lead to poor usability by employees. Furthermore, Lim et al. [3] argued that productivity paradox occurs because of among other things, differences in regulation and environment aspects.

Despite these conflicting facts, organizations persistently invest in IT because they regard that IT adoption is necessary for the realization of high organization performance. Therefore, there is a need to understand further the way IT adoption influences firm performance.

The variety of results provided by previous research indicates that studies on IT adoption should consider contextual factors, within which IT being adopted, in order to properly understand the business values of IT adoption. Current research supports the idea of using Contingency Theory framework to analyze the effectiveness of IT adoption, for example, [8], [13], and [2]. They suggested that the impact of IT adoption is contingent on proposed variables, context, and point of views. Organizations face some contingent factors and these factors affect the quality of decision implementation including a decision on IT adoption [14].

Many of those researchers used variables associated with corporate governance (CG) mechanism such as CEO compensation [13], board-level IT governance [8], Board of Directors [15], Board Independence and foreign ownership [2] as the contextual variables that could influence the relationships between IT adoption and performance variables. The use of CG mechanism factors within IT research is based on Agency Theory perspective. In this point of view, CG mechanisms play essential roles in monitoring investment conducted by a management team. Within IT adoption context, CG aims to ensure that management does not behave unscrupulously by investing firm's money in IT for their interests.

Further, Lazarides et al. [16] stated that a synergy between CG and enterprise systems lead to the achievement of better firm performance. Masli et al. [13] found that contextual factors such as CEO compensation influences relationship between IT spending and firms value. In another study, Turel and Bart [8] showed that IT investment monitoring is a major factor that affects the improvement of firm performance over IT investment. CEO compensation, monitoring, and Board of Directors are part of aspect of CG practices that are quite often used by much of research in CG.

The use of a particular aspect of CG as an essential determinant of the relationship between IT and performance is not without problems. [2], for example, found that the influence of board independence towards the relationship between IT and performance is different for different levels of IT investment. Ho's study indicated there is no moderation effect of board independence. This result does not agree with other empirical evidence that shows board independence positively influences IT returns [17] [18]. Ho et al. [2] added that the differences are due to different variables and methods used. Adams and Mehran [19] Argued that emphasizing on a particular aspect can cause research findings are lack of completeness because it ignores other facets of CG which form the whole system. Further, they reminded that, as a system, governance mechanism and principles must be implemented simultaneously to give impact on firm's value. Some of the system realizations relate to financial performance while others associated with market performance [20].

Based on reviewing previous studies and reasoning presented above, this research aims at analyzing the effect of moderation of CG practices concerning the impact of IT adoption on firm performance. Distinct from previous research, this study uses CG rating, and not a particular aspect of CG, as a moderating variable, which is assumed to influence the effectiveness of IT adoption on firm performance. Furthermore, IT expenditure and the level of IT governance are used as proxies for IT adoption, separately. This study does not use IT investment [2] because of difficulties in obtaining reliable data on IT investment. Therefore, this study is going to investigate whether CG rating moderates the effect of IT expenditure on firm performance and whether CG rating moderates the effect of the level of IT governance on firm performance.

This research is motivated by first, the inconsistency of the results of the previous studies that might be attributed to the use of IT investment proxy and different governance mechanisms. This research tries to analyze both IT expenditure and level of IT governance, separately, as proxies of IT adoption as well as CG rating as the proxy of $\mathrm{CG}$ practice. It is expected that the results of this study can provide empirical support concerning the impact of CG practice towards the business value of IT.

Second, within Agency Theory framework, CG is a mechanism that can reduce agency problems and information asymmetry as a result of ownership and control separation [21]. This research uses CG rating instead of a specific aspect of CG based on the reasoning that governance system that includes structure, processes, and outcomes must be simultaneously implemented to be able to comprehend the resulting impacts completely. 
Third, it is the fact that banking industry is the most competitive and highly regulated one. It is also a vital industry area because of its role as an intermediary between financial service providers. IT for the banking industry is a necessary condition for providing efficient services to its customers, especially in playing its intermediary role. Therefore, the banking industry is chosen as the area being researched.

\section{METHODS}

This research studies banking companies enlisted in Indonesia Stock Exchange from 2011 to 2013. Sample member of this investigation are banks that publish annual reports within this three years period consecutively. Thirty banks satisfy this requirement, and they are used as the research sample.

Data of this research is extracted from the report of each bank, which is available for free access from Indonesia Stock Exchange's website. Typically, an annual report consists of a financial statement, a CG implementation report, and an implementation of corporate social responsibility report. Annual financial reports of the bank are used as the source of IT spending and bank performance data, while the reports of CG implementation are analyzed to obtain governance rating as well as IT governance level data.

In this research, IT spending and level of IT governance are the independent variables, CG Rating is the moderating variable and Return on Assets (ROA) is the dependent one. IT spending represents the expenses related to information and communication technology consisting of computer hardware and software, automatic teller machine as well as communication resources for internet and mobile banking and telephone. The use of IT spending as one of the proxies of IT adoption has also been used by [22]. In case of the banks do not report their IT spending explicitly but state the expense of IT outsourcing, then this amount is used instead. Data for analysis is obtained by calculating the ratio between this IT expenses with respect to the total operational cost of the bank. The higher the ratio, the more important the IT adoption for the bank. From the reports, the minimum value of the ratio is $0.13 \%$, the maximum value is $17.51 \%$, and the mean is $6.28 \%$. There are only four banks with IT spending ratio more than $10 \%$.

The level of IT governance represents the managerial level of the organizational unit that manages the overall IT of the banks. These managerial levels are categorized into strategic and operational levels, which are coded as 1 and 2 , respectively. The higher the managerial level, the more important the IT adoption for the bank. Data shows that there are 13 banks that manage their IT at a strategic level and 17 banks at the operation alone. This categorical variable, which has two values, is equal to one dummy variable. Zero value is assigned to the strategic level, and one is assigned to the operational level.

The CG rating for each bank is calculated by referring Table 1 which is derived from Bank Indonesia regulation [23]. According to this regulation, there are 100 criteria classified into 11 indicators of bank governance as presented in TABLE 1. In this table, CG Rating indicates the level of CG practice.

TABLE 1

CORPORATE GOVERNANCE RATING PROCEDURE.

\begin{tabular}{|c|c|c|c|c|c|c|c|}
\hline No & \multicolumn{4}{|c|}{ Indicators } & $\begin{array}{c}\text { Weight } \\
(\%)\end{array}$ & $\begin{array}{c}\text { Rating Scale } \\
\text { (self-assessment) }\end{array}$ & Score \\
\hline 1 & \multicolumn{4}{|c|}{ Accomplishment of Commissioner's duties and responsibilities } & 10 & $1-5$ & \\
\hline 2 & \multicolumn{4}{|c|}{ Implementation of Director's duty and responsibility } & 20 & $1-5$ & \\
\hline 3 & \multicolumn{4}{|c|}{ Completeness and duty accomplishment of Committee } & 10 & $1-5$ & \\
\hline 4 & \multicolumn{4}{|c|}{ Conflict of interests management } & 10 & $1-5$ & \\
\hline 5 & \multicolumn{4}{|c|}{ Implementation of obedience function } & 5 & $1-5$ & \\
\hline 6 & \multicolumn{4}{|c|}{ Implementation of internal audit } & 5 & $1-5$ & \\
\hline 7 & \multicolumn{4}{|c|}{ Implementation of external audit } & 5 & $1-5$ & \\
\hline 8 & \multicolumn{4}{|c|}{ Implementation of risk management including internal control systems } & 7,5 & $1-5$ & \\
\hline 9 & \multicolumn{4}{|c|}{ Fund provision for related parties and large expenses. } & 7,5 & $1-5$ & \\
\hline 10 & \multicolumn{4}{|c|}{$\begin{array}{l}\text { Financial and non-financial transparency, good CG implementation reports, and } \\
\text { internal reporting }\end{array}$} & 15 & $1-5$ & \\
\hline \multirow[t]{2}{*}{11} & \multicolumn{4}{|c|}{ Strategic Planning of the Bank } & 5 & $1-5$ & \\
\hline & & & Total score & & 100 & & \\
\hline \multirow{3}{*}{\multicolumn{2}{|c|}{$\begin{array}{l}\text { Score } \\
\text { Attribute } \\
\text { CG Rating }\end{array}$}} & $\leq 1,5$ & $1,5 \leq \mathrm{IK} \leq 2,5$ & $2,5 \leq \mathrm{IK} \leq 3,5$ & $3,5 \leq \mathrm{IK} \leq 4,5$ & \multicolumn{2}{|c|}{$4,5 \leq \mathrm{IK} \leq 5$} \\
\hline & & Very good & Good & Fair & $\mathrm{Bad}$ & \multicolumn{2}{|c|}{ Worse } \\
\hline & & 1 & 2 & 3 & 4 & \multicolumn{2}{|c|}{5} \\
\hline
\end{tabular}

Many banks report their CG rating in their annual report based on self-assessment in accordance with the regulation [23]. This self-assessment rates the CG implementation of the bank for each of 100 criteria that are summarized into 11 indicators range from one to five. A score for each indicator is obtained by multiplication of the 
rate with a certain weight. Total score that ranges from one to five determines the CG rating of the bank. In case of the annual reports do not contain self-assessment rating, and then a content analysis is undertaken by this study concerning the report of CG implementation. This study analyses the annual report of the bank by extracting and recording 100 criteria in accordance with the regulation in the same way as the self-assessment.

This procedure results in five banks having CG rating 1, 23 banks having CG rating 2, two banks having CG rating 3 or more. For modeling purposes, these three categories of $\mathrm{CG}$ rating are converted into two dummy variables.

Return on Assets (ROA) is an accounting performance measure which is often used to represent firm performance in accounting research. ROA measures the return on assets that are utilized in operational activities of a firm including IT assets. This study uses ROA as a measure of bank performance. Two multiple linear regression models are applied to investigate the research objectives. First, it is used to model the effect of CG rating, IT expenditure, and the interaction between them on ROA. Second, it is used to model the effect of CG rating, level of IT governance, and the interaction between them on ROA. The interaction term in the model represents the moderating role of $\mathrm{CG}$ rating variable.

\section{RESULTS}

Data is analyzed using linear regression function of a statistical software package, and the results are presented in Table 2. Interpretations of the statistical results are as follows. Considering the role of CG as the moderating variable on the impact of IT expenditure on ROA, it is found that if CG rating is 1 then increasing IT expenditure will reduce ROA. This increase also applies when CG rating is 2, however with much lower ROA. Interestingly, if CG rating is 3 or 4 , without IT spending, ROA will be negative. So, for this CG category, it is necessary to spend more on IT to improve ROA or firm performance. The data shows that different levels of CG have different impacts on the influence of IT expenditure on ROA.

TABLE 2.

REGRESSION ANALYSIS RESULTS WITH BANK PERFORMANCE AS THE DEPENDENT VARIABLE

\begin{tabular}{lcclcc}
\hline \hline \multicolumn{2}{c}{ First model: Adj. $\mathbf{R}^{\mathbf{2}}=\mathbf{0 . 6 8 3}$} & \multicolumn{2}{c}{ Second model: Adj. $\mathbf{R}^{\mathbf{2}}=\mathbf{0 . 7 2 6}$} \\
\hline \multicolumn{1}{c}{ Variables } & Coefficient & p-values & \multicolumn{1}{c}{ Variables } & Coefficient & p-values \\
\hline Constant & -.084 & .000 & Constant & .015 & .211 \\
CG1 & .121 & .000 & CG1 & .033 & .030 \\
CG2 & .101 & .000 & CG2 & -.002 & .897 \\
IT spending & .565 & .000 & Lvl of IT Gov & -.093 & .000 \\
CG1*IT spending & -.617 & .000 & CG1* Lvl of IT Gov & .070 & .002 \\
CG2*IT spending & -.617 & .000 & CG2* Lvl of IT Gov & .093 & .000 \\
\hline
\end{tabular}

With regard to the effect of CG on the impact of IT governance level on ROA, it is found that if CG rating is 1 , then a high level of IT governance will results in better ROA than if the IT governance level is lower. When CG rating is 2, then neither high nor low level of governance influences ROA. On the other hand, when CG is 3 or 4 than a low level of IT governance makes ROA negative. In this instance, the data also shows that different levels of CG have different impacts on the influence of IT governance level on ROA.

\section{DISCUSSION}

As theoretically presented above, CG is a mechanism frequently used by researchers in studies that adopt Agency Theory framework? In practice, CG is believed to be a solution for agency problems because of the occurrence of information asymmetry. Many opportunistic managerial actions, including IT investment, unless properly controlled, could potentially jeopardize the firm's interests. This research supports views that managerial decisions on IT adoption will bring about better banks performance if it is controlled by good CG environment.

The significant roles of CG have been emphasized by many studies because of its ability to improve bank performance, particularly when it is measured by ROA [24][25]. In addition to the role, the regulations require banks to comply with good CG guidance (Bank Indonesia Regulation No. 8/14/PBI/2006 and Circular Letter No. 15/15/DPNP/2013 - Concerning the Implementation of Good Corporate Governance for Commercial Bank). The essence of good CG practice for a bank is to drive the bank to operate more efficiently such that it can perform more actions that are effective, generate a larger cash flow stream and create larger investment opportunities. Evidence from this research also supports this role as the data shows that CG rate significantly influences ROA. 
Masli et al. stated that firm's management could decide to invest significantly in IT to improve firm value [13]. However, as Dewan et al. argued, the investment can be very risk and without successful guarantee [26]. Even, the investment could decrease banks performance in the short term [27]. This large IT investment can become a nondiversifiable risk. Therefore, a CG mechanism helps to optimize resource allocation and monitoring and hence smoothen the risks [28]. Further, CG can reduce the agency cost caused by detrimental management decisions through effective supervision.

\section{A. Corporate Governance and IT Expenditure}

This study provides evidence on the moderating role of CG on the effect of IT expenditure on banks performance. This result supports much of previous research, such as [2] [17] [18] [3]. This study indicates different levels of firm performance for the same amount of IT spending over varying levels of good CG. In this case, a higher CG level leads to better firm performance. This could mean that good CG is an important mechanism in controlling the opportunistic behavior of management in IT investment so that it can improve firm's value.

It has been long, Westland and Clark [29] stated that the need of IT support for a company had been raised drastically, and it was estimated that IT expense accounts for up to $50 \%$ of the capital investment. IT investment has been a necessary condition for banks operation [9] and a strategic part of achieving better profit and competitive advantage [30]. Further, Ssewanyana [31] mentioned that IT could create efficient and effective operations, improve services, control transaction costs, and increase productivity [31]. However, Karim and Hamdan [22] argued that in measuring organization performance as a result of IT adoption a bank must also consider other factors. This study also supports Karim and Hamdan's claim that CG is a factor out of many others that have a significant impact on the effectiveness of IT in improving bank performance [22].

From the Agency Theory perspective, CG mechanism such as independent commissioner appointment, and committee establishment such as IT committee creation, can suppress ineffective management decision on IT adoption. Governance processes implemented through internal control and internal audit can function as control mechanisms for the implementation of disadvantageous IT adoption decision. Therefore, this study does not in line with the productivity paradox assumed by many other studies in IT.

\section{B. Corporate Governance and Level of IT Governance}

The result of this research reveals that CG levels moderate the influence of IT adoption on the bank performance. It shows that the impact of IT adoption is much higher when a bank achieves a high level of good CG practices. In addition to this result, the data also indicates that if the organizational unit that manages the IT of the bank has a strategic position, then the bank performance tends to be higher. As suggested by [1] a high level of IT governance unit assumes that IT is positioned as a strategic mean to realize better firm performance. The research result is also in line with those that found by [8] which showed that organization performance is improved by the increasing level of IT governance. The finding of this study is also supported by [32] and [33]. Empirically they showed that if those who govern IT are members of top-level management, then the financial performance of the firm is much better than if they are part of operational level management.

Being managed by a member of top-level management, the IT adoption is assumed to have strategic values. This kind of IT governance enables a bank to align the IT adoption with other strategic management policies better. This allows the IT to be better designed and operated in supporting fruitful decision making and business processes and operation that eventually improves bank performance.

\section{CONCLUSIONS}

This research has shown the existence of moderation effect of CG level on the impact of IT adoption on bank performance. The effect of this moderation is consistent for both proxies of IT adoption: IT spending and IT governance level. Concluding from the models, it is the fact that different level of good CG results in a different impact of IT adoption on bank performance. Also, when the bank is lacking in CG implementation while on the other hand it is required to invest in IT and keep significant spending on operational IT then, to achieve significant positive impact on bank performance, it is necessary to manage the IT as strategic resources.

These results contribute to both theoretical knowledge and practices. First, this study improves understanding in the impact of IT adoption on bank performance. Especially, the contribution to theory is achieved through further development of the literature in IT governance. The use of managerial levels of IT governance, which are categorized into the strategic and operational level, as a proxy of IT governance adds to the list of proxies of the IT governance identified by [34] that include centralized and decentralized design as well as vertical and horizontal expansions. Second, the result of this study emphasizes the dependable use of IT spending in IT investment research. A meta-analysis conducted by [3] and [35] have found the use of IT spending, IT capability, and IT 
strategy as the operationalization of IT investment and performance measures associated with IT investment. Therefore, this study that argues that IT spending is a special dimension of IT investment related to accountingbased performance measures supports [3].

Third, this research also contributes to the practice of IT governance, especially in the banking industry. This study suggests that IT governance should be assigned to a strategic position so that an investment decision on IT could lead to better bank performance. Another practical implication is that business values of an IT investment will result in having a more competitive advantage for a company.

However, the contribution of this research is constrained by limited data used for analysis and approach utilized to extract data from the reports in addition to possible bias inherently contained in the self-assessment report. Consequently, a more elaborative data analysis is necessary to improve the usefulness of the results.

\section{REFERENCES}

[1] K C Laudon and J P Laudon, Management information system. India: Pearson Education, 2016.

[2] Ho, J L; Wu, A; Xu, S X, "Corperate governance and returns on information technology investment evidence from an emerging market," Strategic Management Jurnal, vol. 32, no. 6, pp. 595-623, 2011.

[3] J H Lim, B Dehning, V J Richardson, and R E Smith, "A meta-analysis of the effects of IT investment on firm financial performance," Journal of Information System, vol. 25, no. 2, pp. 145-169, 2011.

[4] S V Scott, Reenen J Van, and M Zachariadis, "The long-term effect of digital innovation on bank performance: an empirical study of SWIFT adoption in financial services," Research Policy, vol. 46, no. 5, pp. 984-1004, 2017.

[5] Ainin, S; Naqshbandi, M M; Dezdar, S; "Impact of adoption of Green IT practices on organizational performance," Quality \& Quality, vol. 50(5), pp. 1929-1948, 2016.

[6] L Sharma, A Chandrasekaran, K K Boyer, and C M McDemott, "The Impact of Health Information System," vol. 41, pp. 25-41, 2016.

[7] S Tripathy, S Aich, A Cakraborty, and G M Lee, "Information Technology is An Enabling Factor Affecting Supply Chain Performance in Indian SMEs: A structural equation modelling approach," Journal of Modelling in Management, vol. 11(1), pp. 269-287, 2016.

[8] O Turel and C Bart, "Board-level IT Governance and Organization Performance," European Journal of Information System, vol. 23, no. 2, pp. 223-239, 2014.

[9] H Arora and P Arora, "Effect of Investment in Information Technology and Bank Profitability in Niaga," Australian Journal of Businness and Management Research, vol. 13(4), pp. 400-417, 2013.

[10] R Sabherwal and A Jeyaraj, "Information technology impacts on firm performance: an extension of Kohli and Devaraj(2003)," MIS quarterly, vol. 39, no. 4, pp. 809-836, Desember 2015.

[11] M Hajli, J M Sims, and V Ibragimov, "Information Technology (IT) Productivity Paradox in The 21st Century," International Jurnal of Productivity and Performance Management, vol. 64, no. 4, pp. 457-478, 2015.

[12] S S Jones, P S Heaton, R S Rudin, and E D Schneider, "Unraveling the IT Productivity Paradox — Lessons for Health Care," New England Journal of Medicine, vol. 366, no. 24, pp. 2243-2245, 2012.

[13] A Masli, V J Richardson, J M Sanchez, and R E Smith, "The interrelationships between information technology spending, CEO equity incentives, and firm value," vol. 28(2), pp. 41-65, 2014.

[14] D Hwang and H Min, "Identifying the drivers of enterprise resource planning and assessing its impacts on supply chain performances. Industrial Management \& Data Systems," Industrial Management \& Data System, vol. 115(3), pp. 541-569, 2015.

[15] R F Premuroso and S Bhattacharya, "Is there a relationship between firm performance, corporate governance, and a firm's decision to form a technology committee? Corporate Governance: An International Review," vol. 15(6), pp. 1260-1276, 2007.

[16] T Lazarides, E Drimpetas, M Argyropoulou, and J Motwani, "Corporate governance and the information systems excellence factor," International Journal of Business Excellence, vol. 2(1), pp. 16-29, 2008.

[17] J J Choi, S W Park, and S S Yoo, "The value of outsite directors: Evidence from corporate govermance reformin Korea," Journal of Financial and Quantitative Analysis, vol. 42, no. 4, pp. 941-962, 2007.

[18] C S Young, L C Tsai, and P G Hseih, "Voluntary appointment of independent directors in Taiwan: Motives and consequences," Journal of Business Finance \& Accounting, vol. 35(910), pp. 1103-1137, 2008.

[19] R Adams and H Mehran. (2003, April) Is Corporate Governance Different for Bank Holding Companies? [Online]. https://ssrn.com/abstract=387561 or http://dx.doi.org/10.2139/ssrn.387561

[20] L D Brown and M L Caylon. (2004) Corporate Governance and Firm Performance. [Online]. https://ssm.com/abstract=586423 or http://dx.doi.org/10.2139/ssm.586423

[21] R Leung and J Ilsever, "Review of Evidence between Corporate Governance and Mandatory IFRS Adoption from the Perspective of Agency Theory and Information Asymmetry," Universal Journal of Accounting and Finance, vol. 1(3), pp. 85-95, 2013.

[22] A Jalal-Karim and A M Hamdan, "The impact of information technology on improving banking performance matrix: Jordanian banks as case study," in The European Mediterranean and Middle Eastern Conference on Information System, Abu Dhabi, 2010, pp. 21-33.

[23] Indonesia Bank. (2013) Circular Letter Number 15/15/DPNP dated 29 April 2013 Implementation of Good Corporate Governance for Banks, 15/15/DPNP dated 29 April 2013 C.F.R.

[24] D F Larcker, S A Richardson, and I Tuna, "Corporate governance, accounting outcomes, and organizational performance," The Accounting Rewiew, vol. 82(4), pp. 963-1008, 2007. 
[25] Umi Muawanah, "Corporate governance dan kepemilikan keluarga," Jurnal Akuntansi Multiparadigma, vol. 5, no. 2, pp. 287-298, Agustus 2014.

[26] S Dewan, C Shi, and V Gurbaxani, "Investigating the risk-return relationship of information technology investment : Firm-level empirical analysis," Management scient, vol. 53(12), pp. 1829-1842, 2007.

[27] P Wang, "Chasing the hottest IT: effects of information technology fashion on organizations," MIS quarterly, vol. 34(1), pp. 63-85, 2010.

[28] William R Emmons and A Schmid Frank, "Corporate governance and corporate performance," 2000.

[29] J C Westland and T H Clark, Global Electronic Commerce: Theory and Case Studies: The MIT Press., 2000.

[30] O K Agbolage, "Information and Communication Technology and Bank Profitability in Nigeria Australia," Journal of Business and Management Research, vol. 1(4), p. 102.

[31] J K Ssewanyana, "ICT usage in microfinance institutions in Uganda," The African Journal of Information Systems, vol. 1(3), p. 3.

[32] C Ranganathan and S Jha, "Do CIOs matter? Assessing the value of CIO presence in top management teams," vol. 56, 2008.

[33] Qing Hu, Ali Alper Yayla, and Yu Lei, "Does Inclusion of CIO in Top Management Team Impact Firm Performance? Evidence from a Long-Term Event Analysis," in System Sciences (HICSS), 2014 47th Hawaii International Conference on, Hawaii, 2014, pp. 4346-4355.

[34] A E Brown and G G Grant, "Framing the Framework: A Review of IT Governance Research," Communication of the Information System, vol. 15(1), p. 38, 2005.

[35] A Masli, V J Richardson, J M Sancez, and R E Smith, "The business value of IT: A synthesis and framework of archival research," Journal Information System, vol. 25(2), pp. 81-116, 2011. 